\title{
LATVIJAS EMIGRĀCIJAS ĢEOGRĀFIJA
}

\author{
Baiba Švāne, Jānis Kleperis, Elīna Apsīte-Beriṇa \\ LU G̣eogrāfijas un Zemes zinātṇu fakultāte, e-pasts: baiba.svane@lu.lv
}

\begin{abstract}
Anotācija. Laikā kopš 2004. gada no Latvijas emigrējuši 13.6\% iedzīvotāju (CSP, 2015). Mobilitāti veicinošā politika un Eiropas Ekonomiskās zonas darba tirgus atvēršana viesstrādniekiem, devusi iespēju daḷai Latvijas iedzīvotāju par patstāvīgu mītnes zemi izvēlēties kādu no tās dalībvalstīm. Pētījumā par Latvijas iedzīvotāju izceḷošanas ǵeogrāfiskajām tendencēm tika skatītas migrācijas plūsmas no Latvijas uz Lielbritāniju, Īriju, Vāciju, Zviedriju un Norvēǵiju. Rakstā izmantoti pētījuma dati, kas 2012. un 2014. gadā tika iegūti, izmantojot tiešsaistes aptaujas pakalpojumu sociālajā komunikācijas portālā www.draugiem.lv. Aptaujā no Latvijas aizbraukušajiem tika lūgts norādīt dzīvesvietu Latvijā pirms došanās uz kādu no minētajām ārvalstīm. Kādā no mērḳa valstīm esošo respondentu ǵeogrāfiskais izvietojums pirms aizbraukšanas cieši saistīts ar ekonomiskajām attīstības tendencēm valstī. Rīgā un Pierīgā ekonomiskās izaugsmes gados aktīva bija mājokḷu iegādes kreditēšana, kas tālākajos krīzes gados saskārās ar iedzīvotāju grūtībām veikt ikmēneša maksājumus (Apsīte 2013). 2012. gada aptaujas rezultāti parāda, ka vislielākajam respondentu skaitam 22 un $21 \%$ pirms izbraukšanas uz ārvalsti dzīvesvieta bijusi Rīga vai Vidzeme. Savukārt 2014. gada dati atklāj, ka visvairāk respondentu 24 un $20 \%$ bijuši attiecīgi no Kurzemes un Vidzemes, vismazākais skaits respondentu abos pētījuma veikšanas posmos bijis no Latgales - ap 6\% respondentu.
\end{abstract}

Atslēgas vārdi: migrācija, Eiropas ekonomiskā zona, reǵioni, Latvija.

\section{Ievads}

Kopš Eiropas savienības paplašināšanās 2004. gadā, kad Latvija kḷuva par tās dalībvalsti, līdz 2014. gadam no Latvijas ir emigrējuši 13,6\% no pašreizējā iedzīvotāju skaita (CSP 2015). Eiropas Savienības iekšējā ekonomiskā telpa ir atvērta migrācijai starp dalībvalstīm. Lielbritānija, Īrija, Vācija, Norvēǵija un Zviedrija ir galvenie darbaspēka migrācijas galamērḳi no Latvijas, jo šajās valstīs ir vislielākā Latvijas iedzīvotāju koncentrācija. Pētot migrācijas ǵeogrāfiskos aspektus, svarīgi noskaidrot aizbraucēju ǵeogrāfisko sadalījumu, jo, piemēram, Pierīgas reǵiona iedzīvotāji, kur pēdējā desmitgadē palielinājies gan iedzīvotāju skaits un blīvums, gan arī strādājošo darba samaksa ekonomiskās lejupslīdes laikā, kopā ar Rīgas iedzīvotājiem bija paaugstināta riska grupā, nespējot veikt ikmēneša maksājumus, kas savukārt veicināja viņu došanos uz ārvalstīm (Bērziņš 2011; Apsīte 2013). 2012. gadā iegūtie pētījuma dati 
atklāj krīzes migrantu izceḷošanas īpatnības. Līdz ar ekonomiskās situācijas pasliktināšanos Latvijāa daudzi aizbraukušie iedzīvotāji lēmumu par emigrāciju pamato ar nepieciešamību nopelnīt, lai veiktu ikmēneša maksājumus, "lai palīdzētu vīram atdot kredītus", "samaksātu par dzīvokḷa kredītu" (Apsīte 2013). No aptaujātajiem respondentiem 38\% pirms aizbraukšanas mituši tieši Rīgā un Pierīgā. Savukārt pēdējais aptaujas vilnis atklāj aizbraukšanas motivācijas maiņu un pārmaiņas aizbraucēju ǵeogrāfiskajā sadalījumā pēc dzīvesvietas pirms aizbraukšanas.

Pētījuma mērķis ir noskaidrot, kur pirms aizbraukšanas Latvijā patstāvīgi dzīvoja aptaujātie respondenti un kā aizbraukšanas ǵeogrāfija laika gaitā mainījusies līdz ar situācijas maiņu valstī

\section{Materiāls un metodes}

Pētījumā izmantota 2012. un 2014. gadā veiktā LU G̣ZZF Cilvēka ǵeogrāfijas katedras aptauja iedzīvotāju grupās, kas iesaistītas starpvalstu migrācijā no Latvijas uz Lielbritāniju, Norvēgiju, Īriju, Vāciju vai Zviedriju, izmantojot komunikāciju portālu www.draugiem. lv ārvalstīs dzīvojošos lietotājus. Aptaujas dati lietoti, lai noskaidrotu to dzīvesvietu pirms došanās uz ārvalstīm un dzīvesvietu ārvalstīs. Respondentu skaits 2012. gada aptaujā - 2567, bet derīgi 2501, 2014. gadā - 2702. Aptaujas veidošana ar interneta palīdzību arvien plašāk tiek izmatota pētniecībā un ļauj sasniegt ievērojamu skaitu grūti sasniedzamas mērķauditorijas, izvairoties no ǵeogrāfiskajiem šķēršliem (Brickman-Bhutta 2009; Reips and Buffardi 2012; Oiarzabal and Reips 2012; Kissau 2012; McCollum and Apsite-Berina 2015).

\section{Emigrācijas ǵeogrāfija Latvijas reǵionos}

Pētot migrācijas ǵeogrāfiskos aspektus, nozīmīgs ir aizbraucēju ǵeogrāfiskais sadalījums. Pirmais aptaujas vilnis atklāj, ka lielākais aizbraukušo īpatsvars ir no Rīgas un Pierīgas reǵiona. Lielākais aizbraukušo īpatsvars saistāms ar suburbanizāciju, kuras rezultātā valsts centrālajā daḷā ir palielinājies iedzīvotāju skaits un blīvums (Bērziņš 2011). Kopumā samazinājies no Rīgas pilsētas aizbraukušo īpatsvars, no 22\% 2012. gadā aptaujāto līdz 18\% 2014. gadā, bet no Pierīgas aizbraukušo skaits nedaudz audzis no $17 \%$ uz 18\%. Savukārt pieaugusi no Kurzemes aizbraukušo daḷa no $20 \%$ līdz $24 \%$ un no Zemgales no 13\% līdz 14\%. To varētu saistīt ar ekonomiskās aktivitātes un algu paaugstināšanos Rīgā pēc ekonomiskās krīzes. Un ar aizbraukšanas motivācijas maiņu, kas no bezdarba un nepieciešamības nopelnīt mainījusies uz darba perspektīvu trūkumu Latvijā un zemo atalgojumu, strādājot izvēlētajā profesijā. Tādā veidā samazinot ikmēneša maksājumu un kredītu atmaksas nozīmīgumu, kas pašlaik līdzvērtīga ǵimenes apstākḷiem, kas licis pieņemt lēmumu par labu emigrācijai tiem, kuri izceḷoja līdz 2014. gadam. Aptaujāto respondentu ǵeogrāfija 2012. un 2014. gada aptaujās ir līdzīga novadu griezumā, lielākais aizbraukušo respondentu skaits vērojams starp republikas pilsētām un lielākajos Latvijas novados Kurzemē, Zemgalē un Vidzemēē (1., 2. attēls). Tomēr 2014. gadā, salīdzinot ar 2012. gadu, aizbraukušo respondentu skaits turpinājis palielināties novados ar jau iepriekš visai augstu aizbraukušo skaitu. 
Reǵionālajā griezumā Zemgalē un Latgalē, kur ir vismazāk aizbraukušo starp 2012. gada respondentiem, ir lielākais izbraukušo jauniešu vecumā līdz 25 gadiem īpatsvars, savukārt, Rīgā jauniešu īpatsvars starp respondentiem ir viszemākais. Tas saistāms ar aizbraucēju motivāciju doties uz ārvalstīm, jo nespēja veikt ikmēneša maksājumus, tostarp kredītus (Apsīte 2013), kas vairāk varētu skart iedzīvotājus vecumā virs 25 gadiem. Tāpat jau 2014. gadā jauniešu īpatsvars starp respondentiem ir ievērojami sarucis, tikai Latgalē (41\%), tas pārsniedz 30\% robežu.

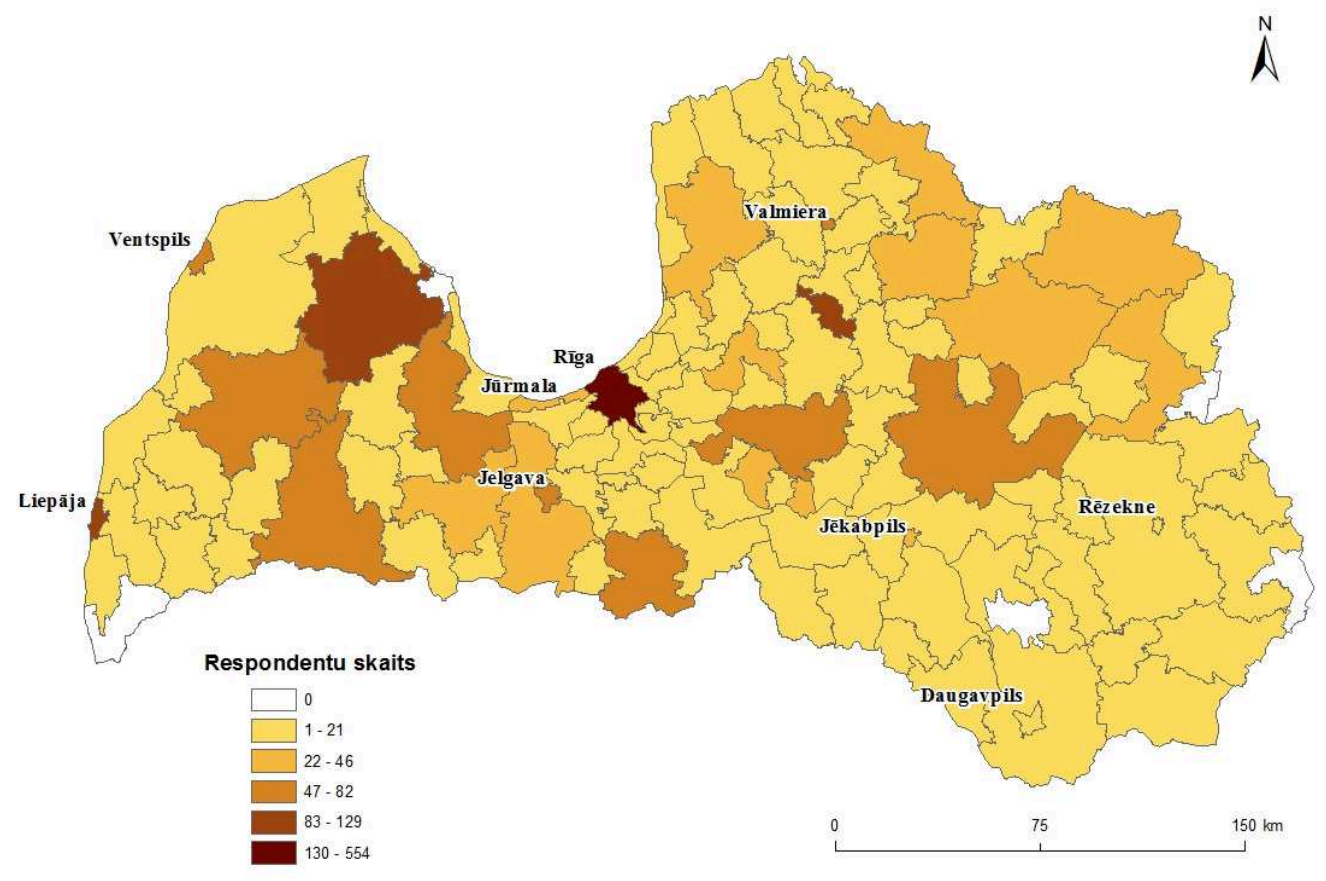

1. attēls. No Latvijas aizbraukušo respondentu geogrāfiskais dalījums reǵionos Latvijā 2012. gadā $(n=2501)$ 


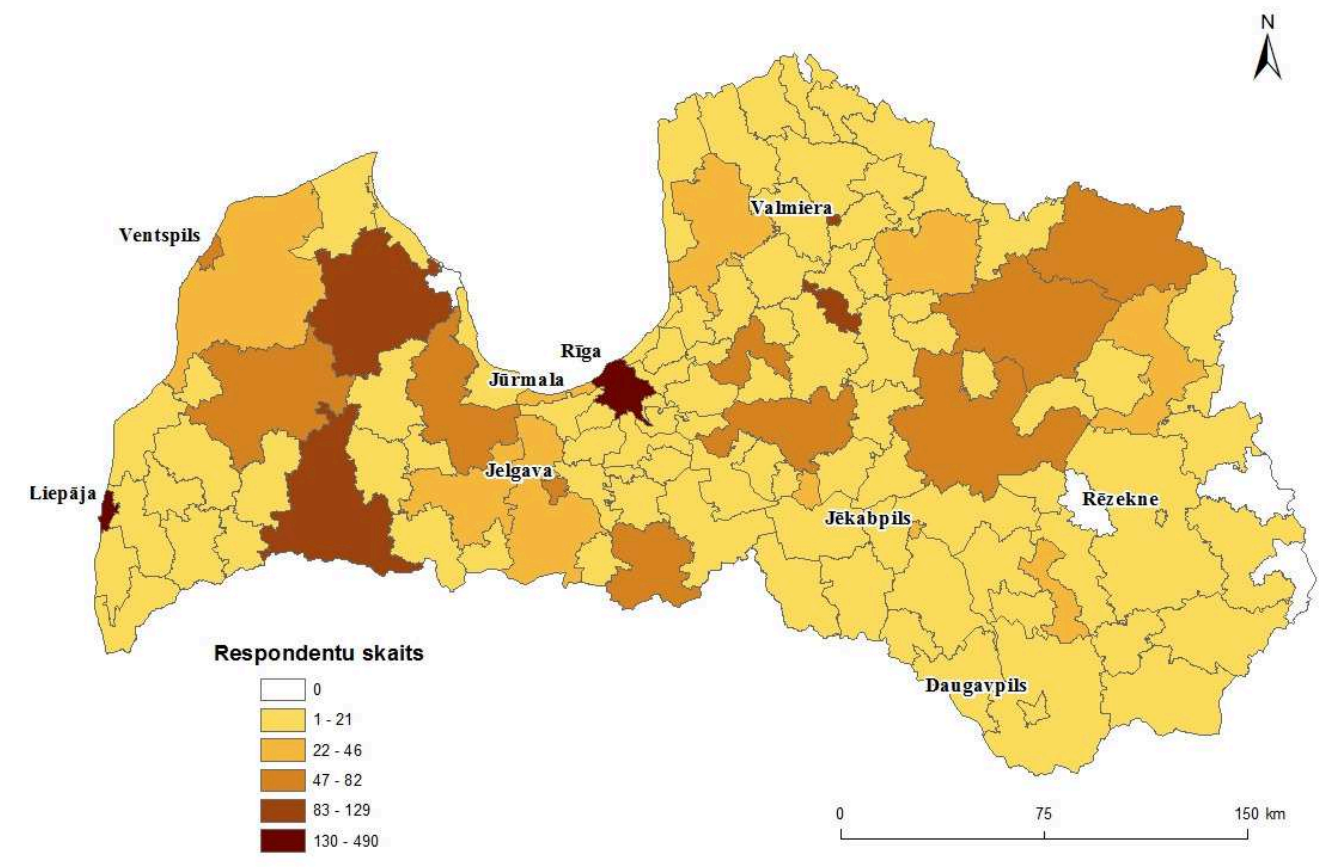

2. attēls. No Latvijas aizbraukušo respondentu ġeogrāfiskais dalījums reǵionos

Latvijā 2014. gadā $(n=2702)$

\section{Secinājumi}

Pētījums par emigrācijas ǵeogrāfiskajiem aspektiem Latvijas un reǵionu griezumā ir būtisks, lai skaidrotu tā norisi un ḷautu spriest par riskiem, kas saistās ar iedzīvotāju aizbraukšanu un reǵionu attīstību.

Ar divu aptauju palīdzību, kas norisinājās 2012. un 2014. gadā, atklājās ne tikai respondentu ǵeogrāfiskais izvietojums pirms aizbraukšanas, bet arī pārmaiņas, kas noris valstī un reǵionos ekonomiskās krīzes un pēckrīzes periodā.

Pirmais aptaujas vilnis l̦auj spriest par tiem, kuri no Latvijas aizbrauca ekonomiskās krīzes laikā. Viṇu galvenais iemesls bija nepieciešamība iegūt augstākus ienākumus, lai segtu ikmēneša maksājumus un vēlme iegūt sociālu un ekonomisku stabilitāti un izvairīties no nedrošības un neskaidrības, ko radīja darba tirgus un sociālie apstākḷi Latvijā. Emigrācijas ǵeogrāfijā tas parādās kā aizbraukšana no valsts centrālās daḷas - Rīgas un Pierīgas un Vidzemes. Savukārt 2014. gada pētījums ḷauj spriest par motīviem, kas licis no Latvijas aizbraukt pēckrīzes periodā. Lielākais aizbraukušo īpatsvars ir no Vidzemes un Kurzemes, bet galvenie aizbraukšanas motīvi saistāmi ar nestabilitāti Latvijas darba tirgū, jo darba perspektīvu trūkums un augstāks atalgojums izvēlētajā profesijā atklājas kā galvenie aizbraukšanas iemesli.

\section{Pateicība}

Raksts izstrādāts ar Valsts pētījumu programmas pētnieciskā projekta Nr. 5.2.4. „Sabiedrības atjaunošana, samazinot depopulācijas riskus, veicinot tautas ataudzi un saiknes ar diasporu" atbalstu. 
Atsauces

Apsīte-Beriņa, E., 2013, Starpvalstu migrācija Eiropas Savienībā: Latvijas iedzīvotāju migrācija uz Lielbritāniju. Promocijas darbs. Latvijas Universitāte

Arango, J. (2000). Explaining migration: a critical view. Social Science Journal 52(165), $283-293$.

Bērziņš, M. (2011). Iedzīvotāju ǵeogrāfiskās mobilitātes loma suburbanizācijas norisēs Latvijā. Promocijas darbs. Latvijas Universitāte

LR Centrālā Statistikas pārvalde (2015). Migrācija. http://www.csb.gov.lv/category/ tagi/migracija (17.02.2016)

Brickman-Bhutta, C. (2012). Not by the book: Facebook as sampling frame. Sociological Methods \& Research, 41(1), 57-88.

Oiarzabal, P. J., Reips, U. D. (2012). Migration and diaspora in the age of information and communication technologies. Journal of Ethnic and Migration studies, 38(9): 1333-1338.

Kissau, K. (2012). 'Structuring migrants' political activities on the Internet: a two-dimensional approach. Journal of Ethnic and Migration Studies, 38(9), 1381-1403.

McCollum, D. and Apsite-Berina, E. (2015). Recruitment through migrant social networks from Latvia to the United Kingdom: Motivations, processes and developments. Migration Letters, 12(1), 50-66.

\section{Summary}

Since the year 2004, more than $10 \%$ of the population of Latvia has emigrated (CSP, 2015). Mobility-promoting policies of the European Economic Area (EEA) and labour markets open to migrant workers made it possible for a large part of the Latvian population to choose another EEA member state as a place of residence. A study of geographic trends in Latvian population emigration investigated migration flows from Latvia to the United Kingdom, Ireland, Germany, Sweden and Norway. Data used were collected through an online survey service in 2012 and 2014. The geographic distribution of respondents' place of residence in Latvia before migration is closely linked to economic development in the country. The results of the 2012 survey show that the greatest number of respondents resided in Rīga or Vidzeme before migrating to another country ( 21 and $22 \%$, respectively) and the main reasons for leaving were the need for higher income and the desire to escape economic instability. By contrast, the 2014 data revealed that the majority of respondents, $24 \%$ and $20 \%$, were from Kurzeme and Vidzeme, and that motivation has changed to low prospects in the local labour market and the wish to earn more within a chosen profession. 